\title{
The "Middleman": A Major Source of Controversy in the Food Industry
}

\author{
CLIFTON B. LUTTRELL
}

\section{$\mathrm{T}$} HE "middleman" in the food industry historically has been the bête noire of many farmers and consumers, This legendary person, allegedly responsible for the differences between the prices of food products received by farmers and the prices paid by consumers, is depicted as having sufficient power over prices to simultaneously underpay farmers for their products and overcharge food consumers. As evidence of this power, it is often noted that a loaf of bread priced at approximately 40 to 50 cents contains only 6 to 7 cents worth of wheat, or that a sirloin steak served in a restaurant for $\$ 10$ or more came from a beef animal sold by the farmer for only 70 cents per pound.

The farmer's frustration with the apparent power of the middleman in the depression years of the early 1870 s led to a rapid expansion of the cooperative movement, by which the farmer expected to eliminate the middleman and retain the profits. ${ }^{1}$ Although farmer-owned cooperatives now operate in almost every stage of farming and food-processing, criticism of the middleman still persists.

\footnotetext{
${ }^{1} H$. E. Erdman in a study for the University of California, Agricultural Experiment Station; published in Henry C. and Anne Dewees Taylor, The Story of Agricultural Economics in the United States, 1840-1932, (Ames: The Iowa State College Press, 1952), pp. 689-92; and Geoffrey S. Shepherd, et. al., in Marketing Farm Products, (Ames: The Iowa State University Press, 1976), p. 252.
}

Criticism of the role of the middleman in the food processing and marketing industry has appeared in numerous studies, hearings, and reports. For instance, one study in 1967 reported that ". . allegations of excessive merchandising costs (of farm products) cannot be brushed aside." The U.S. Department of Agriculture in 1979 reported that "the widening (of food price) spreads to the point where there are probably excess returns over costs is an unwelcome development for consumers and inflation fight-

\footnotetext{
2Harold F. Breimyer, Agricultutal Policy: A Review of Programs and Needs, Technical Papers, National Advisory Com" mission on Food and Fiber (August 1967), p. 103. Other examples of such views include: Report of the National Commission on Food Marketing, Food from Farmer to Consumer (June 1966), pp. jii and 1 , and pp. 109-10; Food Prices, Hearings before the Subcommittee on Production and Stabilization of the Committee on Banking, Housing and Urban Affairs, 93 Cong, 1 Sess. (Government Printing Office, 1973), p. 1 . Food Chain Pricing Activities, Hearings before the Joint Economic Committee, 93 Cong., 2 Sess., (Government Printing Office, 1974), D. 1; The Market Functions and Costs For Food Between Americass Fields and Tables, prepared by Economic Research Service and Agricultural Marketing Service for the Subcommittee on Agricultural Production, Marketing and Stabilization of Prices of the Committee on Agricul ture and Forestry, United States Senate (March 25, 1975); Prices and Profits of Leading Food Chains 1970-74, Hearings before the Joint Econonic Committee, 95 Cong, 1 Sess. (Government Printing Office, 1977); Ward Morehouse, IIr, "Food Retailers Say Carter Shares Blame for High Food Costs," The Christian Science Monitor, August I0, 1979. Also statements by Senator William F. Proxmire and Joseph L. Alioto in Food Chain Pricing Activities, pp. I and 22.
} 
ers." ${ }^{\text {"3 }}$ President Carter was sufficiently concerned with the food marketing industry that he summoned 16 top industry executives to the White House last August and noted that ". . . last winter (of 1978) when food prices were going up (at the farm level), there was no lag in the food-retail spread. Now that they are going down to the farmer, there is a substantial lag."

Implicit in the criticism of the middleman's role is the view that food prices to consumers are established by the middleman independently of farm commodity price movements. ${ }^{5}$ that:

In contrast to this view, it is shown in this article

1. Changes in the portion of retail food costs received by farmers largely result from farm product supply fluctuations that cause changes in the prices of farm commodities rather than from changes in the middleman's share.

2. Changes in the middleman's receipts (gross receipts less the costs of farm products) essentially result from inflation.

3. Changes in farm product prices and inflation are the two primary causes of changes in retail food prices.

4. Retail food prices reflect farm product price changes only after a time lag, and the existence of this lag may account for much of the criticism of the middleman.

\section{Farm Product Price Fluctuations Account for Change in Fammer's Share}

The farmer's share of the cost of a market basket of food (see definition, p. 23) has altered only slightly since the 1920 s as indicated in table 1 . The farmer's share represents the difference between the retail costs to consumers and net receipts of the middleman. It was approximately the same in the $1970 \mathrm{~s}$ as in the $1920 \mathrm{~s}$, averaging 40.9 percent and 40.3 percent in the 1920-29 and 1970-79 decades, respectively. Over the entire period from 1920 to 1979 , the farmer's share averaged 41.5 percent.

Despite the overall consistency of the portion of food costs accruing to farmers during 1920-1979, sizeable fluctuations have occurred in one- to fiveyear periods. These fluctuations reflect changes in

3USDA, Farm Index (September 1979), pp, 4-5.

${ }_{4}^{4}$ Carter Grills Food Industry Executives on Prices and Profits," St. Louis Globe Democrat, August 14, 1979.

${ }^{5}$ Alioto in Food Chain Pricing Activities, p. 22.

\section{Table 1}

Percent of Retail Costs of Food-Farm Products Accruing to Farmers

\begin{tabular}{ll} 
P rears \\
\hline
\end{tabular}

Source USDA Fam Retall Spreads For Food Products, Misedlaneous Piblication No 711 (1972), Agricul tural Statisties, and Farm lndex.

farm product prices rather than changes in receipts to the middleman. Changes in farm product prices are due primarily to changes in short-run supply. Diverse weather and biological conditions, as well as altered international relationships, contribute to yearto-year changes in the supply of farm products. Because the demand for farm products is relatively inelastic, small changes in the quantity produced resulting from abnormal weather or other factors have a relatively large impact on prices.

Some analysts contend that year-to-year changes in production account for the majority of short-run price fluctuations, especially for those crops and livestock products that cannot be stored in large quantities. ${ }^{6}$ Over the longer run, however, factors such as changing international trade policies, wars, and domestic monetary policies have had a significant impact on farm product prices through their effects on farm product demand.

Parallel movements in the farmer's share of the market basket of food and in its real farm value are indicated for selected periods in table 2. Changes in the farmer's share moved in the same direction as real farm value during each period of change since 1947. For example, during the major declines in real value in 1947-49,1951-56, 1958-64, and 1973-76, the farmer's share declined $5,9,4$, and 7 percentage points respectively; and during 1971-73 when real farm value rose $\$ 131$, the farmer's share increased 7 percentage points.

\footnotetext{
ESee William G. Tomek and Kenneth L. Robinson, Agricultural-Product Prices, (Ithica: Comell University Press, 1972), p. 75 .
} 


\section{Definition of the market basket of food.}

"The market basket of food is the average quantity of U.S. farm-originated food purchased annually per household in 1960-61 by families of urban wage earners, clerical workers, and workers living alone. The retail cost is less than expenditures for food by a typical family because:

(1) It does not include costs of food consumed in away-from-home eating establishments.

(2) It is a weighted average of food expenditures by single persons living alone as well as of those by families.

(3) The market basket includes only foods originating on U.S. farms. It does not include fishery products or coffee, bananas, and other imported foods.

"Further, the market basket retail cost is an estimate of the cost of the types and quantities of farm foods purchased by urban wage earners and clerical workers in 1960-61. The types and quantities of food purchased change, at least slightly, from year to year.

"Decreases in the farmer's share are sometimes attributed to substitution of highly processed (convenience) foods for less highly processed or unprocessed foods. The substituted products, it is asserted, have larger farm-retail spreads and higher retail prices relative to their farm values than the foods for which they are substituted. However, changes in the market basket sample are infrequent. When a change occurs, weights are revised so changes in the sample do not alter the total retail cost and farm value. Thus, increased use of convenience foods has not caused the decreases in the farmer's share shown by the present market-basket statistics. The farmer's share, however, has been influenced by changes in marketing services not identified with individual foods. For example, to the extent that more elaborate facilities in supermarkets have increased farm-retall spreads and retail prices, this increase in marketing services has affected the farmer's share."1

1USDA: Agricultural Marketing Costs and Changes, Major Statistical Series (June 1970), p. 3.

Table 2

Change in Farmer's Share, Real Retail Cost, Farm Value, and Middleman's Receipts for Market Basket of Food for Selected Periods'

\begin{tabular}{|c|c|c|c|c|}
\hline Date & $\begin{array}{l}\text { Farmer's share } \\
\text { (percentage points) }\end{array}$ & Retail & $\begin{array}{l}\text { Farn } \\
\text { valuo }\end{array}$ & $\begin{array}{l}\text { Middleman's } \\
\text { receipts }\end{array}$ \\
\hline 194749 & 5 & $\$ \$ \$ 58$ & $\$$ & $8+25$ \\
\hline $1950-51$ & +2 & +35 & +37 & 2 \\
\hline $1951-56$ & 9 & -116 & 4158 & +36 \\
\hline $1957-58$ & +1 & +33 & +22 & +11 \\
\hline $1958-64$ & 4 & 88 & 47 & 10 \\
\hline 196466 & +4 & +38 & +52 & 15 \\
\hline $1966-67$ & 3 & 42 & 39 & 3 \\
\hline 196869 & +2 & 2 & +14 & 16 \\
\hline $1969-71$ & 3 & 42 & -42 & +1 \\
\hline $1971-73$ & +7 & +124 & +131 & 8 \\
\hline 197376 & -7 & 43 & 90 & 147 \\
\hline $1977-78$ & +1 & +35 & +35 & +1 \\
\hline $1947-78$ & & 126 & -194 & +67 \\
\hline
\end{tabular}

Values adjusted for inflation with the consumer price index, The periods selected include those consecuttve years since 1047 diring which the farmers share was either declining or increasing.

Source, USDA, Farm-Retal Spreads For Food Products, Miscellaneous Publication No 74 (1972), Agriciltural Statisties, and Farm Index. 
Char" 1

Real Retail Cost, Farm Value and Farmers' Share of Market Basket of Food

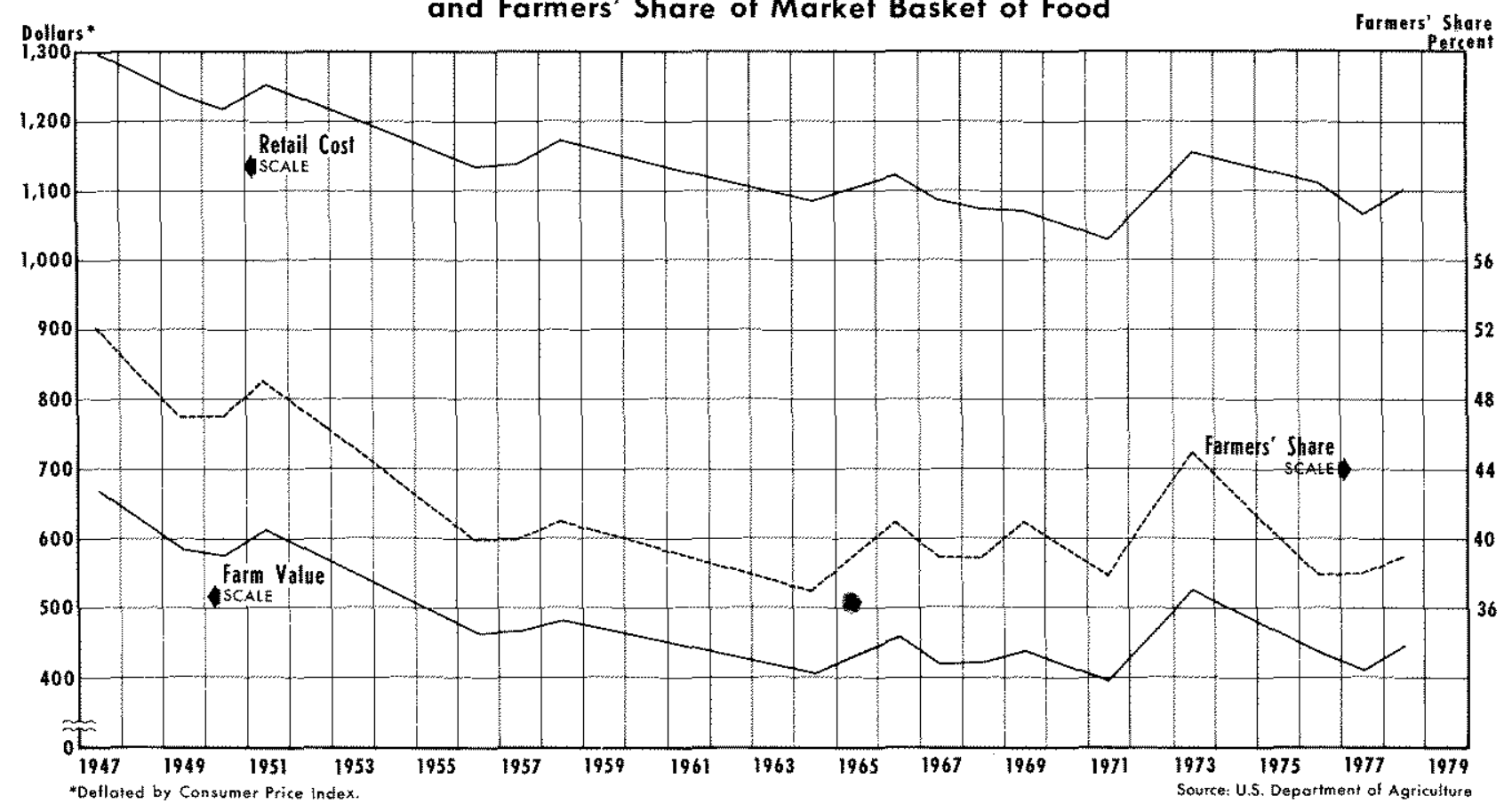

The close relationship between the farmer's share and the real farm value of the market basket of food is illustrated graphically in chart 1. During these selected periods, movement in the farm value of the market basket corresponded to movement in the farmer's share, with sharp changes in farm value associated with sharp changes in the market share accruing to farmers.

\section{Middleman's Receipts Change with Inflation}

The middleman's receipts for the market basket of food are not as variable as the farm value. Weather and other factors that affect the farmer's receipts have less of an effect on the middleman, since changes in demand for resources and output in this sector primarily reflect general inflation rather than weather or other short-run supply or demand disturbances. Consequently, the rate of increase in the middleman's receipts corresponds to the rate of inflation in the overall economy. Table 3 indicates the close relationship between the middleman's return from a market basket of food and the overall rate of inflation as measured by the consumer price index. During some of the periods, namely $1950-55,1955-60$, and 1975-78, the middleman's receipts rose more slowly than the consumer price index. In the periods 1960-65 and 1970-75, however, they rose more quickly than the consumer price index. The rate of increase in the middleman's receipts over the 28-year period averaged 3.8

Table 3

\section{Rate of Change in Middleman's Receipts from Food Sales and Rate of Inflation}

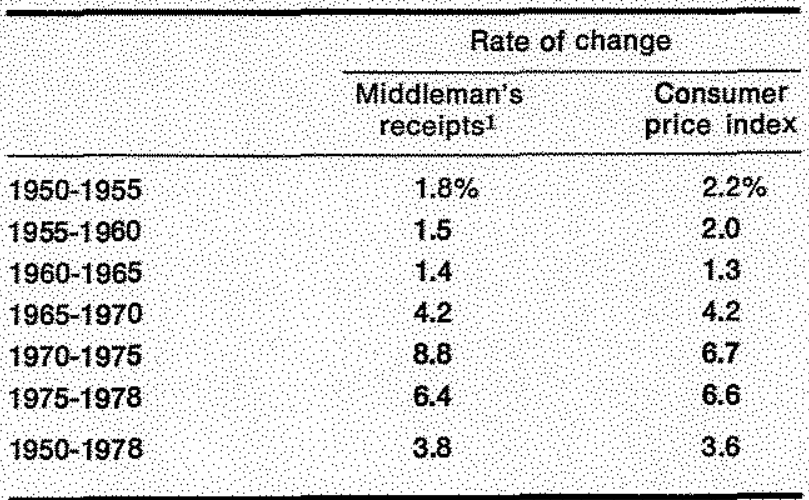

1 Farm-retail spread of market baskel of farn-food produets adjusted for ehange in quantity of tood in market basket.

Sonrce USDA Farm-Retal Spreads for Food Products, Miscellaneous Publication No 741 (1972), p, 106; Agricultural Statistics (1978), p. 446, Agriculturd Outlook (Decomber 1979), p. 16, Economic Re. port of the President (January 1979), p, 240 , and Economic Indicators (December 1979), p 23 


\section{Table 4}

\section{Retail Food Costs Closely Related to Farm Value of Food Products and Inflation}

\begin{tabular}{|c|c|c|c|c|c|c|}
\hline \multirow{2}{*}{$\frac{\text { Years }}{1050-55}$} & \multicolumn{2}{|c|}{$\begin{array}{l}\text { Ghange } \\
\text { in relail } \\
\text { 100d cosis }\end{array}$} & \multirow{2}{*}{$\begin{array}{l}\text { Change } \\
\text { in farn } \\
\text { value } \\
\$, 36\end{array}$} & \multirow{2}{*}{$\begin{array}{l}\text { Impact of } \\
\text { Inflation on } \\
\text { niddieman's } \\
\text { receipts } \\
\qquad 5 \text { ? }\end{array}$} & \multicolumn{2}{|c|}{$\begin{array}{l}\text { Ohange h } \\
\text { farm value } \\
\text { plus impact } \\
\text { or Inflation on } \\
\text { riddleman's } \\
\text { recelpts }\end{array}$} \\
\hline & $\$$ & 46 & & & 9. & 17 \\
\hline 195560 & & 73 & 14 & 68 & & 72 \\
\hline 1960605 & & 41 & 23 & 39 & & 62 \\
\hline $1965-70$ & & 191 & 62 & 143 & & $20 \%$ \\
\hline 197076 & & 648 & 306 & 288 & & 594 \\
\hline $1076-78$ & & 280 & 85 & 232 & & 317 \\
\hline 195070 & 81 & 278 & 9454 & $\$ 812$ & & 267 \\
\hline
\end{tabular}

1Mridileman's receipts. from wakket basket of fam food products at beginning of period nultiplied by the percentage inerease n the consmer price inder dinring the petiod.

Source: USDA, Miscellaveores Publication No. 741 (1972), Tam-Retol spreads for frood

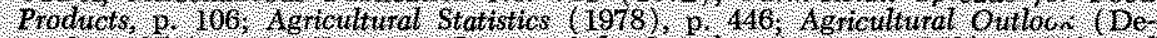

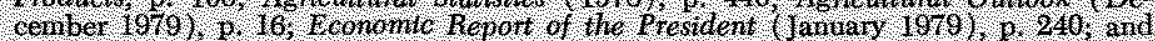
Teonomio Indicators (Decenber 1979 ), o, 23 .

percent per year, or 0.2 percent faster per year than the consumer price index. Essentially all of the increase in the middleman's receipts relative to the consumer price index occurred during 1970-75.

The close relationship between the middleman's receipts and inflation is further demonstrated by assessing the statistical relationship between them. The correlation coefficient between the annual rates of change in the middleman's receipts and the consumer price index for the period 1947-78 is .894.

\section{Food Prices Change With Farm \\ Product Prices and Inflation}

Changes in the retail cost of food are closely associated with changes in the farm value of food products plus the rate of inflation. As shown in table 4 , the change in the farmer's share of the market basket of food, when added to the impact of inflation on the middleman's receipts, accounts for virtually all the change in retail costs of the market basket of food for the 1950-78 period. For example, from 1955 to 1960, the real retail cost of a market basket of food rose $\$ 73$, while the farm value of the original prodncts plus the impact of inflation on the middleman's receipts totaled $\$ 72$. During the more rapid increases in food prices since 1965 , the increase in the farm value of the market basket of food products, added to the impact of inflation on the middleman's receipts, totaled $\$ 1,116$ or 99.7 percent of the increase in the retail cost of the food. As shown in chart 1, after adjustment for inflation, the retail cost of a market basket of food and the farm value of the original food products move almost identically.

An alternative assessment of the relationship between farm value, the middleman's receipts, and retail food costs is obtained by comelating annual changes in retail food costs with those for farm value and the middleman's receipts for the 1947-78 period. After adjusting for inflation, the correlation coefficient between changes in retail cost and farm value is .922 . This value is significantly different from zero at the 5 percent level. In contrast to the significant coefficient of correlation between real retail food costs and the farm value of food, the correlation coefficient between the middleman's receipts and retail food costs is not significantly different from zero at the 5 percent level.

\section{Effect of Time Lag on Prices}

The full impact of farm price changes on food prices occurs only after a substantial time lag. The time lag is related to the timing of food purchases by consumers and the maintenance of food and farm commodity inventories by the middleman. Because 
consumers randomly purchase food day-to-day around some average level, retailers, wholesalers, and processors must hold inventories to accommodate these fluctuations. Consider, for example, the retail outlet specializing in high quality beef. The retailer must carry sufficient stocks to accommodate his customers. Orders are placed to packers for shipments at regular intervals to replenish stocks so that a sufficient amount of beef will be avilable for sale at retailers within seven to ten days after shipment. The packer, in turn, must carry an inventory of cattle ready for slaughter and an inventory of beef ready for shipment to avoid losing customers. He must carry an inventory of slaughter cattle in order to avoid day-to-day fluctuations in slaughtering operations that would impair the efficiency of his labor force, plant, and equipment. ${ }^{7}$

The above description shows that a period of time necessarily elapses before a change in farm output of fed cattle has its full impact on retail price. In fact, several days may pass from the time a reduced number of fat cattle are transferred from the farmer's feedlot to packers' before it is recognized that the reduction in the number marketed is not merely a random Huctuation. Only when cattle and beef stocks are reduced to less than desired levels at both packer and retail levels is the price of cattle bid up and higher prices charged for beef purchases.

This time lag was investigated for a number of food commodities in order to determine the length of time required for retail prices to adjust to changes in farm product prices and the extent to which retail prices change in response to a given change in farm product prices. The following distributed lag price equation was estimated:

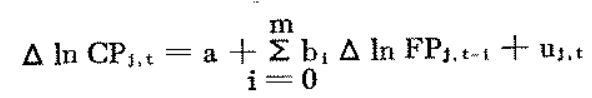

where $\mathrm{CP}_{j}$ and $\mathrm{FP}_{\mathrm{j}}$ are the consumer price and farm price, respectively, of the $j^{\text {th }}$ product. The $b$ 's are the coefficients which indicate the rates of change in the consumer price over each time lag for each percentage change in the farm price of the $\mathrm{j}^{\text {th }}$ product, and $u_{j}$ is the random error term. The " $t$ " subscripts denote the time periods (months).

Thirteen foods or food groups were tested using the Almon polynomial distributed lag technique. The Cochrane-Orcutt procedure was used to correct for

\footnotetext{
7 About one-half of the cattle marketed from commercial feed lots are owned by packers for eight days or more. See Report of the National Commission on Food Marketing, Food from Farmer to Consumer (June, 1966), p. 24.
}

serially dependent disturbances. ${ }^{8}$ Estimates were made for the time period from January 1950 through December 1978, except for fresh fruit, canned hams, round roast, and sirloin steak. For these commodities, the time periods began in January of $1967,1964,1964$, and 1961, respectively. Although lags of 12 periods (months) or more were investigated, the results suggested relatively short 4-month lags, with the exception of cereals and bakery products, white bread, and canned hams which produced 20-, 16-, and 7-month lags, respectively. ${ }^{9}$

The relatively high $R^{2} s$ in table 5 indicate that much of the month-to-month change in the retail price of food is explained by a constant term and relatively recent changes in farm price. For example more than 50 percent of the retail price movement of fresh whole chickens and each of the meats, except bacon and canned hams, is explained by the current and past three-month (or less) lagged change in farm prices. Changes in farm prices account for a large percentage of the change in retail egg prices, but for a relatively small percentage of the change in retail prices of items such as fresh fruit, cereals and bakery products, and white bread. The full impact of changes in farm prices over the effective lag periods are shown in table 6 .

The percentage of the retail price change explained by a change in farm price is directly related to the share of the retail value accruing to the farmer. As shown in table 7, the farmer's share of the retail value of choice beef is relatively high, and 64 percent of the change in the price of beef and veal and 66 percent of the change in the price of chuck roast is explained by the change in slaughter steer prices. Similarly, the farmer's share of the value of eggs is relatively high, and 71 percent of the change in retail egg price is explained by the change in the farm price. On the other hand, only a small share of the retail value of cereals and bakery products and white bread accrues to farmers who produce the wheat from which these products are made. Consequently, changes in farm commodity prices have much less impact on the changes that occur in the retail prices of these products.

If all of the retail food price changes in the short run result from changes in farm prices, the sum of the coefficients (table 6) should approximate the farmer's

\footnotetext{
$8 \mathrm{~A}$ third degree polynomial was assumed. No endpoint constraints were used. All data were seasonally adjusted using the $\mathrm{X}-11$ technique.

9 With the exception of a fow instances that did not materially change the results, the coefficients of any lags that extended beyond the time periods designated in tables 5 and 6 were not significantly different from zero.
} 
Table 5

Rate of Change of Retail Food Prices as a Function of Current and Lagged Rates of Change of Farm Commodity Prices ${ }^{1}$

\begin{tabular}{|c|c|c|c|c|c|c|c|c|c|c|}
\hline \multirow{3}{*}{$\begin{array}{l}\text { Dependent } \\
\text { variable } \\
\text { (change in } \\
\text { retall food } \\
\text { prices) }\end{array}$} & \multirow{3}{*}{$\begin{array}{l}\text { Independent } \\
\text { variable } \\
\text { (change in } \\
\text { farm product } \\
\text { prices) }\end{array}$} & \multicolumn{5}{|c|}{ Coefficients } & \multirow[b]{3}{*}{$\mathrm{R}^{2}$} & \multirow{3}{*}{$\begin{array}{l}\text { Durbin } \\
\text { Watson } \\
\text { statistic }\end{array}$} & \multirow[b]{3}{*}{ Rho } & \multirow[b]{3}{*}{$\begin{array}{l}\text { Standard } \\
\text { error }\end{array}$} \\
\hline & & \multirow[b]{2}{*}{$\begin{array}{c}\text { Constant } \\
\text { term }\end{array}$} & \multirow[b]{2}{*}{ Current } & \multicolumn{3}{|c|}{ Lagged } & & & & \\
\hline & & & & nonth & months & $\begin{array}{l}3 \\
\text { months }\end{array}$ & & & & \\
\hline Fresh vegotables & $\begin{array}{l}\text { Fresh market } \\
\text { vegetables }\end{array}$ & 9.002 & $\begin{array}{r}18 \\
(8.83)\end{array}$ & $(12.43)$ & $(6.39)$ & 2 & 37 & 202 & -264 & .038 \\
\hline Fresh rruit & $\begin{array}{l}\text { Fresh market } \\
\text { fruit }\end{array}$ & $(1.803)$ & $(4.67)$ & $\begin{array}{r}07 \\
(3.23)\end{array}$ & $\begin{array}{r}.06 \\
(3.83)\end{array}$ & $(2.70)$ & .22 & 195 & -.008 & 022 \\
\hline $\begin{array}{l}\text { Cereals and } \\
\text { bakery } \\
\text { products }\end{array}$ & All wheat & $\begin{array}{l}0.003 \\
(781)\end{array}$ & $(2.60)$ & $(4.27)$ & $\begin{array}{c}02 \\
(6.10)\end{array}$ & $(6.85)$ & 32 & 2.03 & 081 & .006 \\
\hline White bread & All wheat & $(6.74)$ & $(4.43)$ & $(6.12)$ & $(6.91)$ & $\begin{array}{r}0.2 \\
(6.24)\end{array}$ & 21 & 1.99 & -085 & .008 \\
\hline $\begin{array}{c}\text { Fresh whole } \\
\text { chickens }\end{array}$ & Broilers & $\begin{array}{r}.001 \\
(0.57)\end{array}$ & $\begin{array}{c}48 \\
(20.84)\end{array}$ & $(13.73)$ & 2 & 2 & 54 & 2.25 & -449 & 028 \\
\hline Bacon & Slaughter hogs & $(1.14)$ & $(6.51)$ & $\begin{array}{r}.28 \\
(16.25)\end{array}$ & $(12.75)$ & 2 & 49 & 200 & -.030 & .025 \\
\hline Ganned hams & Slaughter hogs & $\begin{array}{r}.003 \\
2.37)\end{array}$ & $\begin{array}{r}.04 \\
(255)\end{array}$ & $\begin{array}{r}.07 \\
(7.93)\end{array}$ & $(8.09)$ & $(9.14)$ & .45 & 2.00 & -041 & .015 \\
\hline Meats? & Meat animals & $\begin{array}{r}001 \\
(236)\end{array}$ & $(10.40)$ & $(14.62)$ & $(9.66)$ & 2 & .50 & 2.00 & -.186 & .013 \\
\hline Beef and veal & Slaughter steers & $\begin{array}{r}.002 \\
(3.26)\end{array}$ & $(8.27)$ & (21.47) & $(17.23)$ & 2 & 64 & 1.98 & -194 & .011 \\
\hline Chuck roast & Slaughter steers & $\begin{array}{l}001 \\
(163)\end{array}$ & $\begin{array}{c}13 \\
(6.45)\end{array}$ & $(23.50)$ & $(18.75)$ & 2 & 66 & 2.01 & -259 & 016 \\
\hline Round roast & Slaughter steers & $(2.002$ & $(6: 13)$ & $\begin{array}{r}28 \\
(12.96)\end{array}$ & $\begin{array}{r}.13 \\
(11.19)\end{array}$ & 2 & .55 & 2.13 & -4.12 & .014 \\
\hline Sirloin steak & Slaughter steers & $\begin{array}{r}.002 \\
(2,38)\end{array}$ & $(5.60)$ & $\left(\begin{array}{r}.28 \\
(6.45)\end{array}\right.$ & $(12: 69)$ & 2 & .59 & 2.02 & -407 & .014 \\
\hline Whole milk & Mik & $\begin{array}{r}.001 \\
(3.12)\end{array}$ & $(5.76)$ & $(4.74)$ & $\begin{array}{c}11 \\
(5.72)\end{array}$ & $\begin{array}{c}.08 \\
(2.86)\end{array}$ & 34 & 199 & -200 & .007 \\
\hline Eggs & Eggs & $\begin{array}{r}.000 \\
(0.07)\end{array}$ & $\begin{array}{r}(26.73) \\
(26.73)\end{array}$ & $\begin{array}{r}.14 \\
(7.02)\end{array}$ & 2 & 2 & 71 & 2.26 & -.508 & .028 \\
\hline
\end{tabular}

1 tstatisties are in patenflies is.

2 Instgnificant.

STreludes beef, real, pork, and lamb.

share of the retail food price (table 7). Despite the problem of comparability of some of the food groups, the relationship between the farmer's share and the sum of the coefficients is apparent. For example, the farmer's share of the retail receipts from fresh fruit was 28 percent and the sum of the coefficients for fresh fruit was .32. Similarly, close relationships are noted for pork, meat products, choice beef, and fresh milk. Using the estimated standard error for each sum coefficient, the farmer's share is not significantly different from the sum of the coefficients for five of the nine food groups.

\section{Time Lag Explains Much of}

\section{"Middleman" Complaint}

The lagged impact of farm commodity price changes on food prices explains much of the criticism of the food processing and marketing sector. In general, such criticism has occurred during periods of falling farm prices, when food prices fail to decline in step with farm prices. A look at the lagged impact of a decline in slaughter steer prices on the price of sirloin steak indicates why such views are held. If slaughter steer prices decline from $\$ 1.00$ to $\$ .90$ per 


\begin{tabular}{|c|c|c|c|}
\hline $\begin{array}{l}\text { Dependent variable } \\
\text { (change in } \\
\text { retall food) }\end{array}$ & $\begin{array}{l}\text { Independent variable } \\
\text { (change in } \\
\text { farm product) }\end{array}$ & sumt & $\begin{array}{l}\text { Mean } \\
\text { lag } \\
\text { (months) }\end{array}$ \\
\hline Fresh vegetables & Fresh narket vegetables & $(9.41)$ & 0.9 \\
\hline Fresh fruit & Fresh market fruit & $(5.32)$ & 1.4 \\
\hline $\begin{array}{l}\text { Cereals and bakery } \\
\text { products }\end{array}$ & All wheat & $(10.52)$ & 8.2 \\
\hline White bread & All wheat & $(9.31)$ & 5.7 \\
\hline $\begin{array}{l}\text { Fresh whole } \\
\text { chickens }\end{array}$ & Broilers & $(14.85)$ & 0.6 \\
\hline Bacon & slaughter hogs & $(14.53)$ & 1.3 \\
\hline Canned hams & Slaughter hogs & $(11.38)$ & 3,1 \\
\hline Meats? & Meat animals & $\begin{array}{r}56 \\
(15.70)\end{array}$ & 0.9 \\
\hline Beef and veal & Slaughter steers & $(20.67)$ & 1.2 \\
\hline Chuck roast & Slaughter steers & $\begin{array}{c}.73 \\
(20.18)\end{array}$ & 1.1 \\
\hline Round roast & Slaughter steers & $(11.96)$ & 1.1 \\
\hline Sirloin steak & Slaughter steers & $(14.09)$ & 1.2 \\
\hline Whole nilk & Milk & $(13.74)$ & 13 \\
\hline Eggs & Eggs & $(19.42)$ & 0.2 \\
\hline
\end{tabular}

TDerived from values in table 5 , Includes sum of all coefficients for eurrent and lagged months 4 -month lags except for cercals and bakery produets, white bread and canned Ihans where 20,16 , and 7 nonth lags were used, respectively, $t$-stafistics are in parenthesis

Includes beef, veal, pork, and lamb.

pound ( 10 percent) in the current month, sirloin steak will respond by declining only 1.1 percent $(0.11 \times 10$ percent) during the current month (table 5). ${ }^{10}$ Over a three-month period, however, the total drop in the price of sirloin steak would be 5.7 percent.

The immediate impact of a change in the price of wheat on bread, bakery and cereal products and of slaughter hogs on canned ham is even less than that of slaughter steers on sirloin steak prices. Prices of

10These time lags are averages for the time periods over which the estimates were made. They may have shortened in more recent years if efficiencies in inventory maintenance have been realized. wheat and hogs can decline gradually over much longer periods of time without having a large impact on the consumer price of these products, as shown by the longer lags involved.

The apparent failure of retail prices in recent years to respond immediately to a decline in farm prices reflects the impact of inflation on the middleman's receipts. With higher rates of inflation, food prices often do not appear to respond at all to a decline in farm product prices. For example, given an inflation rate of 12 percent per year, a 10 percent decline in the price of slaughter steers will result in stable sirloin steak prices in the current month. Although the 
Table 7 Farmer's Share of Retail Price and
Sum of Lagged Coefficients of
Specified Foods

\begin{tabular}{|c|c|c|}
\hline Foods & $\begin{array}{l}\text { Farmer's } \\
\text { share }\end{array}$ & $\begin{array}{l}\text { Sum of } \\
\text { coeffictents }\end{array}$ \\
\hline Fresh vegetables & $38 \%$ & 48 \\
\hline Fresh fruit & 28 & 32 \\
\hline Cereals and bakery & 12 & 27 \\
\hline Fryng chickens & 56 & 73 \\
\hline Pork & 55 & 54 \\
\hline Meat products & 57 & 56 \\
\hline Cholce beet & 65 & 59 \\
\hline Fresh milk & 60 & .54 \\
\hline Eggs & 64 & 79 \\
\hline
\end{tabular}

1 Eamer's share and sum of coefficlents from table 5 data were calculated for the sane years.

2 In some instances the retal food group for which the co. efficients were obtained does not precisely correspond with the group in the farmers share eolumm. For example, the sum of the coeffcients for fresh whole dhickens was compared with the famer s share for frying chickens the average of baeom and eanned han with pork, and the average of beef and veal, chick foast, round roast, and sirloin steak with choice beef.

Source, USDA

decline in steer prices will exert a 1 percent downward movement on sirloin steak prices, this will be offset by the impact of inflation on the middleman's cost. This, however, is not evidence that food prices fail to adjust downward in response to declining farm commodity prices. Sirloin steak prices would have risen by 1 percent if the price of slaughter steers had not fallen. Further, there is evidence that food retailers treat increases and decreases in wholesale prices symmetrically - both are passed on fully after the lag between the timing of price changes at the farm and retail levels is taken into account. ${ }^{11}$

\section{Conclusion}

Much of the criticism of the food processing and marketing sector of the economy is based on erroneous perceptions of the food processing and marketing industry. Price movements of farm and retail food products offer no evidence that the middleman manipulates prices.

In the short run, the farmer's share of retail food costs fluctuates quite sharply. However, these fluctuations result almost entirely from changes in farm prices that are caused by changes in short-run supply or demand rather than by changes in the middleman's receipts. The middleman's receipts change at about the same rate and in the same direction as general inflation. Hence, changes in food costs are almost entirely explained by changes in farm prices and in the rate of overall inflation.

Much of the criticism of the middleman apparently stems from a lack of understanding of the time lag between farm price changes and their full impact on food prices. Food prices do not rise and fall in step with the changes in farm prices. Instead, the period of time between the change in farm prices and the full effect of this change at the retail level varies from about two months for eggs to more than a year and a half for cereals and bakery products. Consequently, retail food prices may remain stable during the first few days following a sharp decline in farm prices, and they may even rise temporarily if general inflation is at a high rate. Nevertheless, retail food prices eventually move either up or down in response to farm price changes and the rate of overall inflation.

11Dale Heien, "A Study of the Relationship Between FarmLevel Prices and Retail Food Prices," prepared for the Conncil on Wage and Price Stability (September 1976). For a discnssion of the function of inventories in pricing see Armen A. Alchian and William R. Allen, University Economics, 3rd ed. (Belmont, California, Wadsworth Publishing Company, Inc., 1972), pp. 139-41.

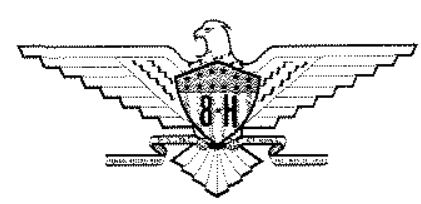

